\title{
Zosimos of Apollonia-Sozopolis
}

\author{
Peter TALLOEN* - Maya PRODANOVA**
}

\section{Introduction}

Saint Zosimos of Apollonia-Sozopolis, a soldier who was reputedly martyred in the border region of ancient Pisidia and Phrygia (SW Turkey) during the reign of the emperor Trajan (98-117 AD) after resigning from the Roman army to become a Christian, is a relatively unknown saint celebrated by the Greek Orthodox Church on the $19^{\text {th }}$ of June, a date given by both versions of his Passio (see below); the Synaxarium Ecclesiae Constantinopolitanae situates his feast day on June 20. His worship in late antique and Byzantine times has received little scholarly attention so far: he is absent, for example, in the recent overview of local saints and martyrs of Anatolia presented by Sylvain Destephen, and has only a skeleton entry in the Oxford Database on the "Cult of Saints in Late Antiquity". ${ }^{1}$ This can be partly explained by the fact that there are few testimonia for his cult. He is known from a synaxarian notice (elogium), preserved in three very similar versions. One is included in the Menologion of Basil II (976-1025 AD), the second in the Synaxarium Ecclesiae Constantinopolitanae - a collection of brief notices of saints commemorated in the churches of Constantinople arranged by feast, ordered by the emperor Constantine VII Porphyrogenitus (945-959 AD) - and the third, including more details of his tortures, in the Menaion for the month of June ( $11^{\text {th }}$ century). ${ }^{2}$ Furthermore, there are two versions of his Passio - the account of the saint's martyrdom. One version is published in the Acta Sanctorum and the other by B. Latyšev in his Menologion. ${ }^{3}$ Finally, there are two Byzantine akolouthia or arrangements of a Divine Service for Saint Zosimos. ${ }^{4}$

In modern scholarship, the saint is briefly mentioned by Clive Foss in his article on pilgrimage in Anatolia. Furthermore, he is discussed by Christopher Walter as Zosimos Kephalophoros in a short article of 2001, and in his book on the "Warrior Saints", as a soldier who originated from

* Assist. Prof. Peter Talloen, Süleyman Demirel University, Dept. of Archaeology, Isparta, Turkey (petertalloen@sdu.edu.tr; http://orcid.org/0000-0001-9644-3073); Assistant director of the Sagalassos Archaeological Research Project, directed by Prof. Jeroen Poblome of the University of Leuven (Belgium).

** Maya Prodanova, PhD fellow at Humboldt University of Berlin and the Berlin Graduate School of Ancient Studies (writing her dissertation on the Rise of Christianity in Thrace and Lower Moesia), (prodanom@hu-berlin.de; https://orcid.org/0000-0001-9926-613X).

The authors would like to thank professors Cilliers Breytenbach and Stephen Mitchell, as well as Philipp Pilhofer, for the organisation of a workshop at the Humboldt University in Berlin in June 2018 which made this article possible. It has especially benefitted from the comments and improvements made by Stephen Mitchell and the two anonymous reviewers. Any remaining errors are their own.

${ }^{1}$ Destephen 2015, 59-116; for the entry in the Oxford database see:

http://csla.history.ox.ac.uk/record.php?recid=E06663 (last accessed on 09/01/2021).

${ }^{2}$ See Menologium Graecorum, col. 504, Synax. CP, col. 757, and M $\eta v \alpha \iota \alpha$, respectively.

${ }^{3}$ AASS, Iun. III, 813-816 (= BHG 1888) and ML II, 79-82 (= BHG 1888c).

${ }^{4}$ Codex Lesbiacus Leimonos 11, 55-56 and 130-131. 
ancient Apollonia Pontica - Sozopolis in the Roman province of Thracia on the western Black Sea coast, and resigned from the Roman army in Pisidia, where he was martyred. ${ }^{5}$ Walter made this identification on the basis of a $19^{\text {th }}$ century icon kept at a small church dedicated to Saint Zosimos in the Bulgarian city of Sozopol. This icon depicts the saint standing holding his decapitated head, the origin of the epithet kephalophoros.

This characterisation of Zosimos as a Thracian soldier by Walter is a case of mixed identities, or better, of mixed origins. It is the aim of this article to demonstrate that the Apollonia-Sozopolis referred to in the sources concerning the saint is not the Bulgarian city of Sozopol where the saint is still venerated today but the homonymous city located in the northwestern part of ancient Pisidia in modern Turkey. A textual analysis of the Passio of Zosimos will offer several indications for this.

As with many stories about saints, the question whether this example has any historical basis cannot be answered. Nevertheless, this article will look for the origins of the Passio of Zosimos, in both space and time. The martyrdom is first mentioned in a manuscript dating to the $10^{\text {th }}$ century: the Synaxarium. ${ }^{6}$ Yet, several elements mentioned in the text demonstrate that the account of the saint's martyrdom was most probably a late antique construct, part of the abundance of hagiographical texts produced in late antiquity. We will argue that it could have been composed to emphasize the position of Apollonia-Sozopolis as a major centre of early Christianity within the province of Pisidia during the $5^{\text {th }}$ and early $6^{\text {th }}$ centuries.

There is subsequent evidence for his veneration at Gračanica in Kosovo and at Sozopol in Bulgaria, and the paper will try to establish why the cult of this Pisidian saint eventually came to be centred at Sozopol in Bulgaria, where he is still the object of veneration today.

\section{The Passio of Saint Zosimos}

An English translation of the text of the Passio of Zosimos found in the Acta Sanctorum (= BHG 1888 , hereafter $A A S S$ ) follows, accompanied by discussion of the elements relating to the origin of the saint and the location of the martyrdom. The differences in Latyšev's Menologion (= BHG $1888 \mathrm{c}$, hereafter $M L$ II) will be summarised in the footnotes after every section.

1 In those days, when Trajan was emperor, great madness and delusion by the idols and great blindness ruled the Gentiles; and many persecutions against the Church of God were initiated. A certain Dometianus, who ruled over Pisidian Antioch, appeared before the emperor Trajan and requested authority against the Christians, so that he might subject to terrible punishment whomever would not offer sacrifices to the gods. When this man took such power and put on the Devil's armour, he roared like a lion against those who died in the confession of God; he yet went to Apollonia, through the city of the Sozopolitans. ${ }^{7}$

\footnotetext{
${ }^{5}$ Foss 2002, 135 n. 41; Walter 2001, 40-44; Idem 2003, 166-167. A newly published article shows that the saint is still usually considered as a local saint from Thracia despite the evidence of his Passio: see Paskaleva 2019, 224-234.

${ }^{6}$ Synax. CP, col. 757.

${ }^{7}$ The version of the Passio reported by Latyšev in his Menologion (hereafter ML II) consists of eight sections as opposed to nine in the AASS. Although no essential information (martyr's and governor's name, occupation, place and time of trial and execution) differs between the versions, the emphasis attached to
} 
2 When the persecution was about to break out, a certain Zosimos, who was a soldier, having heard of the faith of the Christians, threw away the arms of war and resorted to the most holy Church; and after he had been deemed worthy of the faith in our Lord, Jesus Christ, and had undergone the bath of immortality in great faith and chastity, having prayed God, he was struggling in long fasting. After many days had passed, when Dometianus went through the city which has already been mentioned, someone came to him and reported about the holiest Zosimos: "There is one Zosimos, a soldier, who despises the emperor and your power; who threw away the arms and refused (to perform) his military service, to which he was entitled by the emperor Trajan; he says he himself is of the religion of the Christians and thinks that our gods are (worth) nothing; but he also abominates the legislations of the emperor and despises his authority." The governor then ordered to hand him over, by saying: "Bring the so called Zosimos to the tribunal!" So, a unit of soldiers departed, in accordance with the governor's order, caught Zosimos and handed him over before the tribunal. Here the governor interrogated him by saying: "Are you the one called Zosimos?" He then replied and said: "I am Zosimos, servant of my Lord, Jesus Christ." The governor said to him: "First, declare of which social class you are, and you proclaim yourself a servant like this." Zosimos said: "I am a soldier according to rank, and I left your gods of the destruction, and became a Christian." The governor Dometianus spoke: "Unholiest Zosimos, you are in any way served by this name (of yours); come and offer sacrifice to the gods, so that your initial contempt would be forgiven you, that you have insulted the emperor and our lord Trajan who has granted you the position in the military!" Zosimos said: "I won't sacrifice to the demons." Dometianus said: "Let him be taken to prison!"8

3 On the next day, he again ordered him to be brought before the tribunal. The officers then bound his hands behind his back and handed him over to the governor. The governor then ordered that he is hung from a tree. After he was hung so, he (Dometianus) spoke to him: "Unholiest Zosimos, sacrifice, before I destroy you while you are tied to your limbs!" Zosimos said: "Not only when you command by words but even if you fulfill this by deeds, you won't persuade me to sacrifice." Dometianus said: "Let him be beaten as is common for a soldier!" After the blessed one was beaten for a long time, he spoke to the governor: "Why are your officers struggling for nothing? For through God who strengthens me I don't take notice of your strikes." After he was beaten (again) for a long time, and the soil was filled with his blood, he cried with a loud voice: "Lord Almighty, you who is sitting on the unshakable throne, you who has stretched out the sky and has laid the foundations of the Earth, and has gathered all the waters, (you) hope of us, your servants: Hear

the various elements of the story is different. The $M L$ II presents a shorter version of some passages and puts stress on others by going into more detail.

1. In $M L$ II Zosimos is introduced already in the first section as a soldier who refuses to obey the pagan rules, so he goes to the Church and gets baptised, i.e. the section combines elements from 1 . and 2. in the AASS. Neither Apollonia nor Sozopolis is mentioned at the beginning.

${ }^{8}$ 2. In this section of the $M L$ II the governor goes to Apollonia through Sozopolis and is informed about Zosimos. Among the accusations most emphasis is put on the claims of Zosimos that the gods are worth nothing: “. . he says they could neither speak, nor hear, and could do absolutely nothing”. The first questioning of the martyr by the governor is missing. It is presented in part 3. where Jesus Christ is referred to as "the immortal great King" by the martyr, whereas the pagan gods are described as "gods without souls". The importance of the soul stands out in contrast to the AASS version, for the martyr also declares that nobody could lead him astray from the love towards Christ, even if Dometianus would be eager to "deprive (him) of the soul itself". 
me who is begging you and don't let me be defeated by these threats, in order that through me all who don't know your name understand that you are the One God." And while he was praying this, a voice from the skies came to him saying: "Be strong, Zosimos, and behave like a man! For I am with you and no one will bring distress upon you!" And everyone (else) held the voice within, also Dometianus heard (it), and some of those who were there said: "He is a magician!", whereas others said: "No, but great is the God of the Christians and his is the voice which came to him!"”

4 The governor then ordered again to stretch him while bound from all four sides. Having been pulled in an extremely violent way, the martyr turned his face to heaven and began to speak: "Lord God, (you) who understands the mind of people, (you) hope of the Christians, (you) refuge and peace for the ones being oppressed, save me from the intention of the destroyer and slanderer Dometianus so that the people, who are present, understand that you are God, the living one, who goes forward and remains (the same) throughout the centuries!" When they saw the endurance of the martyr, a lot of the people who were there believed in God. But when the governor saw what was happening and that everyone was about to come to faith in the Lord, he felt ashamed and clenched his teeth, and considered by what kind of death to destroy him. ${ }^{10}$

5 Then he ordered that he be put on a copper bed and tied (to it) violently; and after a great fire was lit, he ordered that the blessed one be thrown, delivered over to it (the fire). But after the saint made the sign of the cross and was dropped (into it), the Lord immediately turned the fire into dew, for also the help of God appeared through the angels. But all the people, who were there, said that because of the great fire he had expired. But the angels of God, who stood by, raised the holy martyr from the bed and put him down in front of everyone. This crowd, who had been watching the wonders of God, gave praise to the Lord who sent forth his angels and released him from such a fire; and again, most of the people believed in the Lord. ${ }^{11}$

6 The governor called the holy martyr next to him and said to him: "You should have been persuaded, Zosimos, and should have offered sacrifice to the gods!" Zosimos said: "You most defiled with blood from all the people, what kind of gods will you order me to sacrifice to?" The governor then said: "Zeus and Hera." Zosimos said: "I don't serve the many, for I recognize one living God, whom alone I serve piously." When the governor heard this, he said to him: "I am telling you, Zosimos, you will go to the fire and you will burn!" Zosimos said: "Insensible one, once and for all I am telling you, that I only serve the Lord who is in the Heavens!"

\footnotetext{
${ }^{9}$ In the version of the $M L$ II, this section from the AASS corresponds to part 4. Zosimos is brought before the tribunal and asked to sacrifice which he refuses. He is beaten violently but not hung from a tree as in AASS. However, his prayer to the Lord appears shorter. The Lord is referred to as the Almighty and the one who is omniscient, but a detailed description of his creation is missing. At the end, this part mentions that Dometianus orders to stretch the martyr on all four sides which is the only mention of this torture and is not elaborated further unlike the description in the $4^{\text {th }}$ part of the AASS. The second prayer of Zosimos to God is absent.

${ }^{10}$ Only the last sentence corresponds to $M L$ II, section $\mathbf{5}$.

${ }^{11}$ Both texts (AASS and $M L$ II) narrate the torture with the metal bed in section 5. In ML II the martyr is delivered to the fire naked. Zosimos speaks again to the Lord and asks him to show his wonders. The angels immediately grab hold of him, so he remains unscathed, but they stay invisible. Zosimos is asked again to sacrifice. And, once again, he stresses that the gods which he is asked to venerate, cannot help because they are "made of stone and wood". Later, at the end of the section, Zosimos also calls them "deceitful". Unlike in AASS, part 6, Zeus and Hera are not mentioned.
} 
The governor then stood up from the tribunal and was about to make a journey by road to the city of the Konanans; he ordered that the martyr would follow (him) while bound and that he would be delivered to the fire in this place. And when Dometianus went to the city to take his place on the tribunal, he ordered to put nails on soldiers' boots and to hammer them on the feet of the martyr, and to put (him) in chains so that he should walk tied to race horses. But he, who was bound to the young animals, did not succumb while walking but was running in front of the horses; because with him was God who became his helper; and his mouth opened, and he said: "Lord, you who adjusts my feet (to be) like the ones of a deer, give me power to endure till the end!" When the governor saw the endurance of the martyr, he ordered to keep him locked up and to give him no food at all. ${ }^{12}$

7 But after three days had passed during which he did not take to himself any food, two men were seen in (his) prison, one of them carried bread, the other one a vessel of water; and they spoke to the martyr: "Accept these precious gifts which were sent to you by the Lord, your God!" And after he took (from them), thanking God, and ate, he said: "I praise you, Lord, that you have saved me and have not despised me but that you have satiated me with your heavenly food! I am praising and glorifying your greatness throughout the centuries! Amen!"

When the morning came, and the governor took (his) place on the tribunal, he ordered the holy martyr to be brought before (him). The holy Zosimos then stood up (before him) with a bright face and in great tranquillity. The governor was astonished that after he had undergone such torture of the feet, his face did not fall. And answering (this astonishment?) the governor spoke: "Zosimos, you should finally sacrifice to the gods, so that you don't die badly in torture!" Zosimos said: "If you want to sacrifice to your equals, sacrifice. But I, as I said before, serve (only) the Lord, my God." Dometianus then became frantic and said: "He should be hung from the tree!" When he was hung up, the governor said: "You miserable one, do you see how many chastisements have been set before you? Aren't you going to listen to me and sacrifice?" Zosimos said: "The ones who love the living God don't take thought for those (tortures)." The governor then said: "The sinner should be clobbered!" While being clobbered he screamed and prayed, saying: "I discovered (now) fully your good hearth, o Christ, giver of light, for you are the one who has taught me not to speak impiously, so that I fully understand your divine nature through these tortures!"13

8 When he said these things, the governor, who did not accept (this) with great satisfaction, ordered that he would be brought down and close to the tribunal; and coming in front of the tribunal, Dometianus said to him: "You have been put through a lot of tortures in the name of Christ, and you have not helped yourself even once, so now come forward, and offer sacrifice to the gods!" Zosimos said: "Dometianus, you, cruel and inhuman, and guilty of all impiety, you should be seized with fear of God, who is in the Heavens, and you should forget the deceit which surrounds

\footnotetext{
${ }^{12}$ In the $6^{\text {th }}$ section of $M L$ II Dometianus is about to go to Konana and orders (like in the AASS) that the martyr is pulled behind him, wearing soldier's boots fixed with sharp nails. In contrast to the version of the AASS, however, the race with the horses is not mentioned and neither is the prayer to the Lord. When they arrive, the martyr does not receive food for three days $(=7$. AASS $)$, after which the angels of the Lord appear before him and give him gifts: one of them carries bread, the other one mixed wine.

${ }^{13}$ Unlike this passage in the AASS, the version in the ML II, part 7., does not report a further punishment of the martyr by beating but instead lets the governor pronounce a death sentence over him. He is accused of putting down the military service and dishonouring the emperor. The final judgement over Zosimos is to be decapitated by the sword.
} 
you and shall not call the idols gods, (because) these are demons." The governor then said: "Unholiest, do you dare to call the gods, worshipped by the world, demons?" Zosimos said: "Their worship has been arranged by your emperor, for those who believe in them." The governor said: "Zosimos, do you turn against the gods and make them angry, so that through your blasphemy also we come to a miserable end?" Zosimos said: "By reason of piety and agreement with God I am turning against you." The governor spoke: "Put burning torches to him and hold (these) on his belly!" Zosimos said: "Don't bring me only torches; but even if you burn my whole body, you will not defeat me! For Christ is next to me and strengthens me! And I am eager to be destroyed by you; for this is my glory in Christ." 14

9 Because the governor no longer knew what to undertake, especially as he did not perceive the thoughts of the saint and did not benefit (from them) in whatsoever manner, he ordered that he would be decapitated. Led away in order to be executed the martyr began to speak: "Lord, my God, look upon me, the sinner, and admit my soul together with the ones who got relief through you throughout the ages, because you are my glory, from now on until eternity!"

The holy Zosimos was delivered in the month of June, on the $19^{\text {th }}$, in the city of the Konanans, under emperor Trajan, when our Lord, Jesus Christ, ruled over us, glory and power to him for all eternity! Amen! ${ }^{15}$

(AASS, Iun. III, 813-16; Iun. IV, 676-79 = BHG 1888, translation by M. Prodanova).

To be clear, the actual birthplace of the saint is nowhere mentioned in the text. The personal name Zosimos, meaning "viable" or "likely to survive", was too common throughout the Greek-speaking eastern part of the Mediterranean, especially in the Roman Imperial period and late antique times, to provide any clue about his origin. ${ }^{16}$ However, the text of his Passio leaves no doubt that the entire story of the martyrdom was set in the ancient region of Pisidia, in southwestern Asia Minor, ruling out any original connection with Bulgarian Sozopol.

Firstly, the Roman governor who ordered the execution of Zosimos, a certain Dometianus, is said to have "ruled over Pisidian Antioch" (paragraph 1), a city located on a hill outside the town of Yalvaç north of the river Anthios (nowadays the Yalvaç Çay), in the modern Turkish province of Isparta. ${ }^{17}$ The Seleucid colony of Antiocheia (pros Pisidia) was established by Antiochos I (281$261 \mathrm{BC}$ ) or his successor Antiochos II (261-246 BC) as one of several city foundations along the major Seleucid military route connecting western Asia Minor with the Cilician gates, and later refounded as the Roman colony of Antiochia ad Pisidiam by the emperor Augustus (27 BC-14 $\mathrm{AD}) .{ }^{18}$ The presence of a governor indicates that the city was the provincial capital. While Pisidia

${ }^{14}$ This final torture in the AASS is not reported by the ML II. The detailed discussion between Dometianus and Zosimos is also missing.

${ }^{15}$ In the final, $\mathbf{8}^{\text {th }}$ part of the $M L$ II, it is also stated that Zosimos is delivered on the $19^{\text {th }}$ of June and buried at Konana. Unlike the AASS, in which this very end is short, a more detailed appeal to the reader and praise to the Lord are included in the $M L$ II.

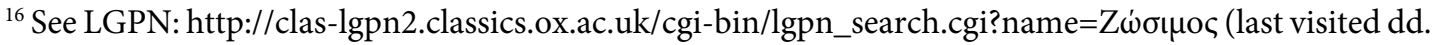
09/01/2021).

${ }^{17}$ On the ancient city of Pisidian Antioch see Belke - Mersich 1990, 185-188; Mitchell - Waelkens 1998.

${ }^{18}$ For the Seleucid colony see Cohen 1995, 278-281; Mitchell - Waelkens 1998, 5-7. The Roman colony is discussed by Mitchell - Waelkens 1998, 8-11. 
was an eparcheia or official administrative region of the Roman Empire at least since the reign of $\mathrm{Nero}^{19}$, it only became an actual province in the late antique period, more specifically in AD 309, as a result of the Tetrarchic provincial reorganization; Antioch became the capital of the newly founded province. ${ }^{20}$

Governor Dometianus, after consulting with the emperor Trajan, is said to have gone on a tour of persecution "to Apollonia, through the city of the Sozopolitans" (paragraph 1) where the soldier Zosimos was stationed. Although Sozopolis has been interpreted by Walter as the region in which Apollonia was situated ${ }^{21}$, Apollonia and Sozopolis are in fact two attested names of the same city, located at the town of Uluborlu in the province of Isparta, some $70 \mathrm{~km}$ southwest of Pisidian Antioch (Fig. 1). Like Pisidian Antioch, Apollonia was a Seleucid colony, founded at the settlement of Mordiaion on the border of Pisidia and Phrygia Paroreios by Antiochos I or II in the $3^{\text {rd }}$ century BC.22 Because of its theophoric origin, the city changed its name - Apollonia, after Apollo the divine protector of the Seleucid dynasty ${ }^{23}$ - into Sozopolis, "city of salvation" or perhaps "the Saviour's City", in late antiquity. Judging by a letter on the subject of Apollinarianism written by Basil of Caesarea to the people of Sozopolis ca. AD 377 this name-change must have occurred prior to this date. ${ }^{24}$ While this letter, as part of correspondence between members of the clergy, could still be considered a private document, not necessarily reflecting the official situation, the fact that the city is equally mentioned as Sozopolis in the bishops' lists of the Ecumenical Council of Constantinople in AD $381^{25}$ irrefutably indicates that this had become the new, official name of the city by that time. During the stay of the governor at Apollonia, Zosimos, who renounced serving in the army, was arraigned before him $^{26}$; Dometianus interrogated the deserter, attempted to suborn him and subjected him to torture.

After his arrest, interrogation and initial torture at Apollonia, the saint was taken by the governor on "a journey by road to the city of the Konanans" (paragraph 6), where he was imprisoned for three days and underwent further torture before being executed. The small and rather inconspicuous city of Konana is located at the town of Gönen in the province of Isparta, about $15 \mathrm{~km}$ southeast of Apollonia-Sozopolis ${ }^{27}$ and was also part of the late antique province of Pisidia. The transport edict issued in AD 14/15 by Sextus Sotidius Strabo Libuscidianus, the governor of

\footnotetext{
${ }^{19}$ On the eparcheia of Pisidia see Vitale 2012, 133-143.

${ }^{20}$ On the late antique provincial capital see Christol - Drew-Bear 1999, 39-71.

${ }^{21}$ Walter 2001, 40-41.

${ }^{22}$ On the city of Apollonia-Sozopolis see Belke - Mersich 1990, 387-388; Cohen 1995, 285-290.

${ }^{23}$ Seleukos was reputedly Apollo's son, and all members of the whole dynasty liked to stress kinship with the god: Mehl 1986, 5-6 and 304-305.

${ }^{24}$ Basil, Letters, ep. 261; Belke - Mersich 1990, 387. Apollinarianism is a Christological concept proposed by Apollinaris of Laodikeia in Syria (died 390) that argues that Jesus had a normal human body but a divine mind instead of a regular human soul, cf. Baldwin - Kazhdan 1991, 136.

${ }^{25}$ Mansi, vol. III, col. 570 D.

${ }^{26}$ Not before the emperor as mentioned by Walter 2001, 40.

${ }^{27}$ On the ancient city of Konana see Belke - Mersich 1990, 311; Hürmüzlü - De Giorgi - Iversen 2009, 197-220.
} 
Galatia under Tiberius, mentions Konana as one of the cities responsible for the cursus publicus on the Via Sebaste or Imperial Highway. ${ }^{28}$

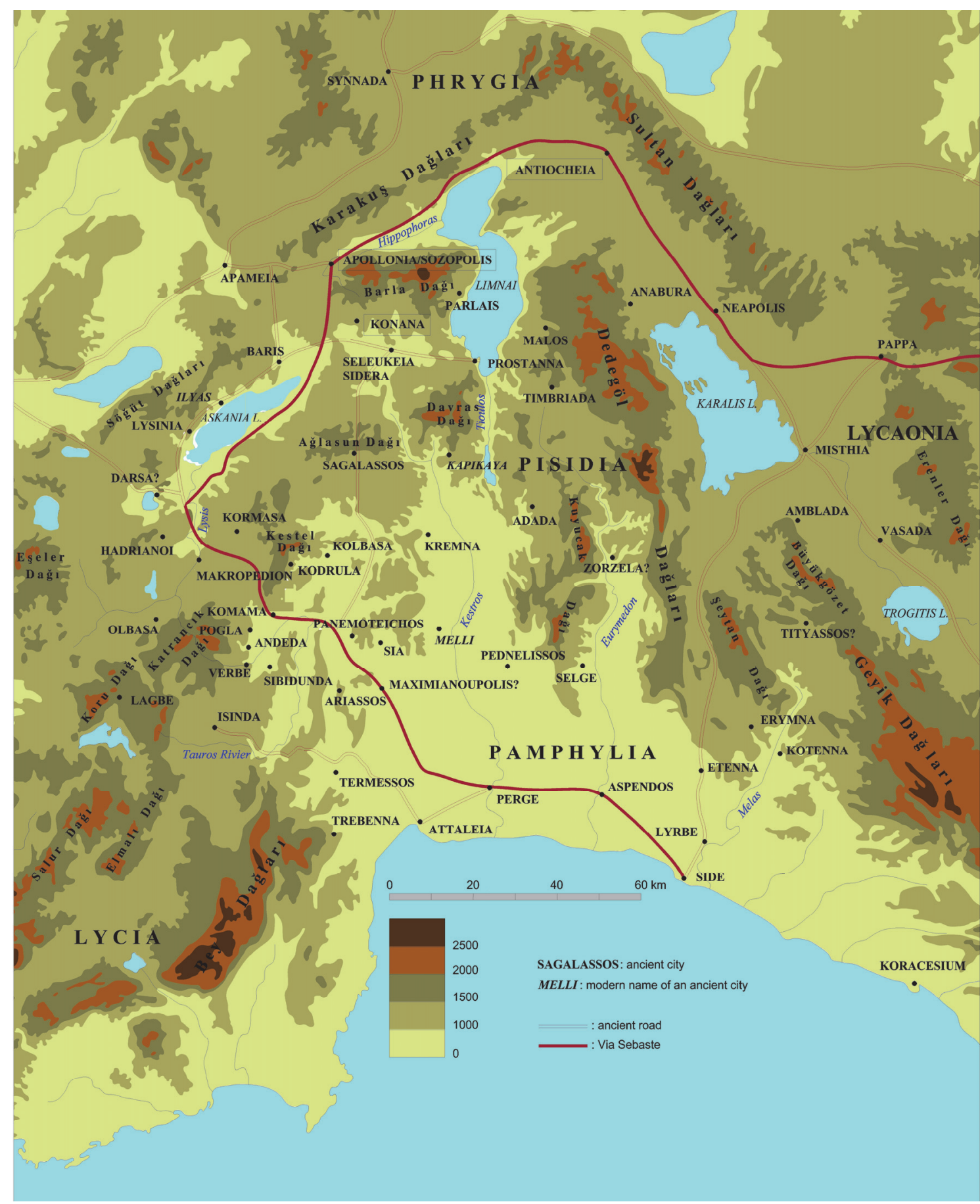

Fig. 1) Map of ancient Pisidia (Drawn by Eliane Mahy, KU Leuven)

Its role in the Roman road network is also confirmed by milestones mentioning Konana as caput viae of the branch leading to the Via Sebaste. ${ }^{29}$ This ran from the southwest through the territory of Sagalassos to Konana, and continued north to Apollonia passing the modern village of İğdecik

\footnotetext{
${ }^{28}$ See Mitchell 1976, 106-131. On the importance of the Via Sebaste see Talloen forthcoming.

${ }^{29}$ See Iversen $2015, \mathrm{n}^{\circ} 58-59,62$ and 64.
} 
where several of the mentioned milestones have been found, before turning east to the main Roman colony, Pisidian Antioch. It would make sense for a governor, based in Pisidian Antioch, to visit Konana after Apollonia on a provincial tour.

The geographical proximity of all three locations mentioned in the acts of the martyr leaves no doubt that the entire story of the martyrdom of Zosimos was situated in the region of Pisidia, ruling out any original link with the homonymous Thracian city of Apollonia-Sozopolis as contended by Walter. We will come back to the relationship with Bulgarian Sozopol later on.

\section{The origin of the Passio and the cult of Saint Zosimos}

Although all the available sources related to Saint Zosimos date to the Middle Byzantine period or later, several elements in the text suggest a late antique origin for his Passio. Firstly, the governor is stationed at Pisidian Antioch, known to have been the capital of the late antique province of Pisidia since AD 309 (see above). The establishment of the province in that year thus provides us with a terminus post quem for the writing of the Passio.

The old provincial structure dissolved after the later $7^{\text {th }}$ century, as Anatolia was reorganised into military regions or themata. Civil provinces or eparchiai became shadowy administrative entities within larger military commands and disappeared completely in the course of the $8^{\text {th }}$ century. ${ }^{30}$ Pisidia thus became part of the Thema Anatolikon. Pisidian Antioch remained the metropolis of the ecclesiastical province of Pisidia at least until the second half of the $12^{\text {th }}$ century ${ }^{31}$, but from the late $7^{\text {th }}$ century onwards it was administratively subordinate to Amorium, the capital of Thema Anatolikon. While we cannot completely exclude the possibility that the author (or authors) described an anachronistic provincial situation, it is far more likely that he (or they) will have used the contemporary situation to make the acts intelligible to their readers. In that case, the later $7^{\text {th }}$ century gives us a terminus ante quem for the codification of the Passio.

Another argument for a date in late antiquity is the fact that the ancient name of Apollonia which did not appear in official documents after AD 381 (see above) - occurs in combination with the new name of Sozopolis. This is an argument for composition soon after the name change while people were still aware of the old name. The change of name was most probably intended as a form of damnatio memoriae, meant to erase the pagan identity of Apollonia from common memory and replace it with Christian Sozopolis, as can also be seen at Aphrodisias where the pagan theophoric city name was erased from public inscriptions and replaced by Stauropolis. ${ }^{32}$ The old name may not have been widely remembered after the change; the $7^{\text {th }}$ century Vita of Saint Theodore of Sykeon, who lived from the middle of the $6^{\text {th }}$ century to AD 613, records that the saint made a pilgrimage to the shrine of the Theotokos at Sozopolis in search of a cure for an eye ailment, but makes no reference to Apollonia. ${ }^{33}$ Konana, on the other hand, was not given the

\footnotetext{
${ }^{30}$ See Brubaker - Haldon 2011, 724-728.

${ }^{31}$ Antioch is last mentioned as metropolis of Pisidia in the $16^{\text {th }}$ notitia of Notitiae episcopatuum (composed in the middle of the $12^{\text {th }}$ century; see Notitiae episcopatuum, 388) after which the seat was (temporarily?) transferred to Sozopolis, see Belke - Mersich 1990, 186. Yet, some sources suggest that Antioch resumed its function as seat of the metropolitan during the $13^{\text {th }}$ century before being abandoned in the $14^{\text {th }}$ century (Métivier 2012, 249).

32 See Roueché 2007, 183-192; Smith 2012, 300-302.

${ }^{33}$ Vie de Théodore de Sykeon, 106-109.
} 
imperial name of Justinianopolis recorded by the Notitiae episcopatuum from the second half of the $6^{\text {th }}$ to late $8^{\text {th }} /$ early $9^{\text {th }}$ century. ${ }^{34}$ This would indicate the reign of Justinian (527-562 AD) as terminus ante quem.

Other elements in the text appear to be fictitious. First of all, although set during the reign of Trajan, the Acts do not reflect the division of provinces at that date, when Pisidian Antioch and Apollonia belonged to the Roman province of Galatia, with Ankyra as capital. ${ }^{35}$ So we are certainly dealing with a later construct. It is inconceivable that the governor was actually given the authority to persecute Christians by Trajan. ${ }^{36}$

Furthermore, no late antique governor of Pisidia called Dometianus - a variation of the more usual name Domitianus - is known from Pisidia, although Domitianus is recorded as the name of a comes of Lycaonia in the Acts of Saints Iulitta and her small son Cyricus, early Christian martyrs from the city of Iconium. ${ }^{37}$ Mother and child fled the city to escape persecution by governor Domitianus. They went to Tarsus in nearby Cilicia where they were eventually arrested and put to death in $\mathrm{AD} 304$, also in the month of June ( $16^{\text {th }}$ of June).

There is also no evidence for a Roman military base at Apollonia-Sozopolis where Zosimos, characterised as a Roman soldier (paragraph 2), could have been stationed, either in the $2^{\text {nd }}$ century $\mathrm{AD}$ or in late antiquity. Sozopolis first became an imperial military strongpoint only during the Middle Byzantine period when it is attested on seals from the $9^{\text {th }}$ century onwards as the seat of a tourmaches, the commander of a tourma or military detachment of some 3000 men. ${ }^{38}$ Sozopolis remained a strong frontier bulwark against the Seljuks until it was finally captured in $1182 .{ }^{39}$

The Acts of the saint therefore appear to have be largely fictitious but written in the late antique period by somebody who used several elements particular to the region, and specifically the topography, in order to make the story of the martyrdom more credible. ${ }^{40}$ Late antiquity was a period in which many lives and acts of saints were written down, a time with a lively tradition of

${ }^{34}$ Justinianopolis appears among the bishoprics of Pisidia in Notitia I (composed in 610-641 AD; Notitiae episcopatuum, 212), Notitia II (composed in 805-814 AD; Notitiae episcopatuum, 226) and Notitia III (composed in 787-869 AD; Notitiae episcopatuum, 239); in Notitia IV (composed between 805-814 and $827 / 828$ AD) it appears again as Konana (Notitiae episcopatuum, 258). On the identification of Konana as Justinianopolis see Belke - Mersich 1990, 311.

${ }^{35}$ Christol - Drew-Bear 1987, 13-19; McKenchie 2019, 188. At that time Konana, like the rest of Pisidia, was most probably part of the province of Lycia-Pamphylia with Perge as capital, cf. Uytterhoeven - Poblome forthcoming.

${ }^{36}$ Perhaps this early setting was inspired by the renowned correspondence between the emperor Trajan and Pliny the Younger who, as governor of Bithynia, asked the emperor for advice and guidelines in dealing with the Christians (Plin. Epist. X, 96-97).

${ }^{37}$ See AASS, Iun. III, 17-24; Jones et al. 1971, 262: Domitianus 2.

${ }^{38}$ see Zacos - Veglery 1972, n² 2643; Belke - Mersich 1990, 387.

${ }^{39}$ See Foss - Winfield 1986, 139-140; Belke - Mersich 1990, 387; Beihammer 2017, 151 and 376.

${ }^{40}$ The example of the fictitious martyrdom of Ariadne of Prymnessos in Phrygia is discussed by Robert 1980, 244-256. 
hagiography. ${ }^{41}$ The Passio of Saint Zosimos shows similarities with that of other warrior saints, who were martyred under Diocletian and his co-emperors, when the latter wished to purge the army of Christians. Yet, the date of his martyrdom, during the reign of Trajan is placed exceptionally early and as a result Zosimos became inscribed in the list of the few ancient but prestigious martyrs that characterized the early Christianized regions. ${ }^{42}$ This date perhaps intended to emphasize the role of Apollonia as one of the early centres of Christianity in the region. The text on several occasions (paragraph 3-5) speaks of locals of Apollonia-Sozopolis converting to Christianity when witnessing Zosimos' belief in the Lord. Conversely, this is not mentioned for the inhabitants of neighbouring Konana, although the saint also spent several days there before being executed. Thus, the text appears to be focusing on the Christians of ApolloniaSozopolis at the time of the martyrdom. Such an early date for the local Christian community is corroborated by material remains as well as the literary tradition.

Christian tombstones from the city and its territory can be dated as early as the $3^{\text {rd }}$ century, which makes them the first material evidence for Christianity in the region. ${ }^{43}$ This exceptionally early date was perhaps the result of the presence of a Jewish community at Apollonia, as in other Seleucid colonies in the wider area. ${ }^{44}$ Given that Saint Paul travelled on the Via Sebaste from the Pamphylian harbour city of Perge to Pisidian Antioch ${ }^{45}$, he must have passed through Apollonia and may even have stopped to preach there to the community. ${ }^{46}$ Also at nearby Seleukeia (see Fig. 1), Saint Paul allegedly made a stop and appointed Artemon as first bishop of the city. ${ }^{47}$ During the later $4^{\text {th }}$ century, as mentioned above, Saint Basil of Caesarea wrote to the people of Sozopolis to answer questions on the matter of Apollinarianism. In later times, Apollonia-Sozopolis remained an important centre of Christianity. It was the hometown of Severus (c. 465-538), the patriarch of Antioch and one of the greatest theologians of late antiquity advocating monophysitism ${ }^{48}$, and also the location where a famous icon of the Theotokos was kept, which exuded a miraculous oil. ${ }^{49}$ This made the church of the Virgin Mary the object of pilgrimage, and the fame of the myron, which was bottled and exported, widespread. The miraculous oil exuded by the icon was held to be effective against disease and miscarriage. In an epistle regarding the veneration of icons, read at the $7^{\text {th }}$ Ecumenical Council (AD 787), Germanus, Patriarch of Constantinople referred to the

\footnotetext{
${ }^{41}$ See Efthymiadis et al. 2011, 35-94.

${ }^{42}$ For an overview of the early martyrdoms in Anatolia see Destephen 2015, 59-60 and 65.

${ }^{43}$ See Buckler - Calder - Guthrie 1933, n 219-224; see also McKenchie 2019, 187-209. On the evidence for early Christianity in Pisidia see Talloen 2015, 200-202.

${ }^{44}$ On the Jewish presence at Apollonia and neighbouring cities see Talloen 2015, 202-203. Generally, on Jewish presence in inner Anatolia (Phrygia and Pisidia) see Mitchell 1993, 32-37.

${ }^{45}$ See Mitchell 1993, 6-7; Talloen forthcoming.

${ }^{46}$ Ramsay $(1890,401)$ even identified it as the location of the church founded by Mark, the cousin of Barnabas and companion of Saint Paul, mentioned in AASS, Iun. III, 41. Yet, the fact that (John) Mark left Paul and Barnabas in Perge and returned to Jerusalem rather than travelling with them to Pisidian Antioch (Acts 13:13) seems to suggest that this Apollonia has to be sought elsewhere.

${ }^{47}$ Le Quien vol. I, col. 1053.

${ }^{48}$ See Gregory 1991, 1884-1885.

49 On the icon of the Theotokos at Sozopolis see Vie de Théodore de Sykeon, 106 and 108-109; http://csla.history.ox.ac.uk/record.php?recid=E05332 (last visited dd. 09/01/2021).
} 
antiquity of "the icon of the Most-immaculate Virgin Theotokos, found in Sozopolis of Pisidia, and streaming myrrh from the depiction of the arm". ${ }^{50}$

The promotion of a local saint with an exceptionally early martyrdom, and the codification of his Passio in late antiquity can perhaps be seen as part of the community's efforts to establish itself as one of the leading Christian centres of the region. The provincial capital of Pisidian Antioch naturally came first: it was not only the seat of the archbishop or metropolitan of Pisidia and one of the first Christian communities, dating back to the first missionary journey of Saint Paul ${ }^{51}$, but also home to several saints - Marina (or Margaret) and Marcus (or Mark) the shepherd, who converted his brothers Alphius, Alexander and Zosimos, and the trio Neon, Nikon and Heliodoros - all of whom were supposedly martyred during the Great Persecution under Diocletian. ${ }^{52}$ Yet, following the metropolis of the ecclesiastical province there will have been several cities competing for the places of honour within the church hierarchy as expressed in the Notitiae episcopatuum. The Notitiae clearly defined the position and rank of each metropolitanate, archbishopric and bishopric, something which depended on the ancient tradition of a particular city as a seat of Christianity, the size of that particular city, and its importance in the provincial administration. ${ }^{53}$

Competition for privileges granted by the imperial authorities was widespread among Roman cities, and glorious origins - either historical or mythical - often served as tools for advancing one's case ${ }^{54}$ Legendary founders and renowned poliad deities played an important role in this. Once polytheism was officially abolished - judging by the name change, this occurred during the second half of the $4^{\text {th }}$ century at Apollonia-Sozopolis - communities identified new holy protectors of the city and its inhabitants, a role often attributed to local saints. ${ }^{55}$ Their cults were also used as instruments to enhance the status of the community. ${ }^{56}$ The presence of a very early martyr would certainly have contributed to the prestige of Apollonia-Sozopolis within the new Christian Empire, and provided it with a powerful instrument to secure its position within the ecclesiastical hierarchy of the province, and perhaps even led it to aspire to more.

Having said that, no material evidence related to the worship of Saint Zosimos, which would corroborate such a local promotion of the cult, has so far been registered at the site of ApolloniaSozopolis or in its immediate vicinity. The limited amount of archaeological research conducted

\footnotetext{
${ }^{50}$ Mansi, vol. XIII, col. 622 C5-8; Brubaker - Haldon 2011, 100.

${ }^{51}$ See Mitchell 1993, 7-8.

${ }^{52}$ On the martyrs of Pisidian Antioch see Sauget 1966, col. 1150-1160 (Marina), and Roman Martyrology, September 28 (Mark the Shepherd and his converts).

${ }^{53}$ See Vryonis 1964, 118.

${ }^{54}$ See Robert 1977, 1-39 for the famous rivalry between Nicaea and Nicomedia, and Nollé 1993, 297-317 for the competition between the cities of Pamphylia. For the region of Pisidia see Talloen 2015, 314-317.

${ }^{55}$ See Destephen 2015, 80-81, who sees this exclusive connection between saint and civic community as a development from the second half of the 5th century onwards.

${ }^{56}$ See e.g. Carlà 2010, 197-272. On the cults of Saint John and Saint Polycarp, used in the struggle between the cities of Ephesos and Smyrna, see Destephen 2015, 81.
} 
in the area may be partly responsible for this.$^{57}$ Although Foss suggests a sanctuary for the saint at Konana - his place of execution - no traces of a martyrium dedicated to Zosimos have been recorded there either. ${ }^{58}$ The only location where the cult of the saint is attested with certainty is the city of Sozopol in present-day Bulgaria, though he may also have been venerated at Gračanica in Kosovo.

\section{Saint Zosimos at Gračanica}

In the church of the renowned $14^{\text {th }}$ century monastery of Gračanica, located in modern Kosovo, the martyrdom of Saint Zosimos has been incorporated in the scenes from the northwest dome of the building, illustrating the saints' days in June of the Byzantine church calendar (Fig. 2). ${ }^{59}$ The saint is depicted seated on the ground wearing civil clothing - a long tunic and cloak - at the moment right after the decapitation, with his head in a halo fallen onto his lap. Behind him stands a soldier who puts his sword back into the scabbard. Above the scene there is the legend: o $\alpha$ o $\gamma(เ \circ)$

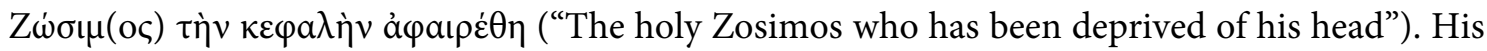
martyrdom is represented at the bottom left corner of a wall decorated with the month's other martyrs and saints: On the top register we see (from left to right) Saint Methodius of Patara $\left(20^{\text {th }}\right.$ of June), Saint Joseph, Saint Asyncritus and his companions (20 $0^{\text {th }}$ of June), Saint Peter, and Saint Terentius of Iconium ( $21^{\text {st }}$ of June); on the lower register Saint Zosimos, Saint Julianus of Egypt, Saint Eusebius of Samosata (22 ${ }^{\text {nd }}$ of June), and the group of Saint Aristokles the presbyter, Saint Demetrianus the deacon, and Saint Athanasius the reader, condemned to the flames ( $23^{\text {rd }}$ of June).

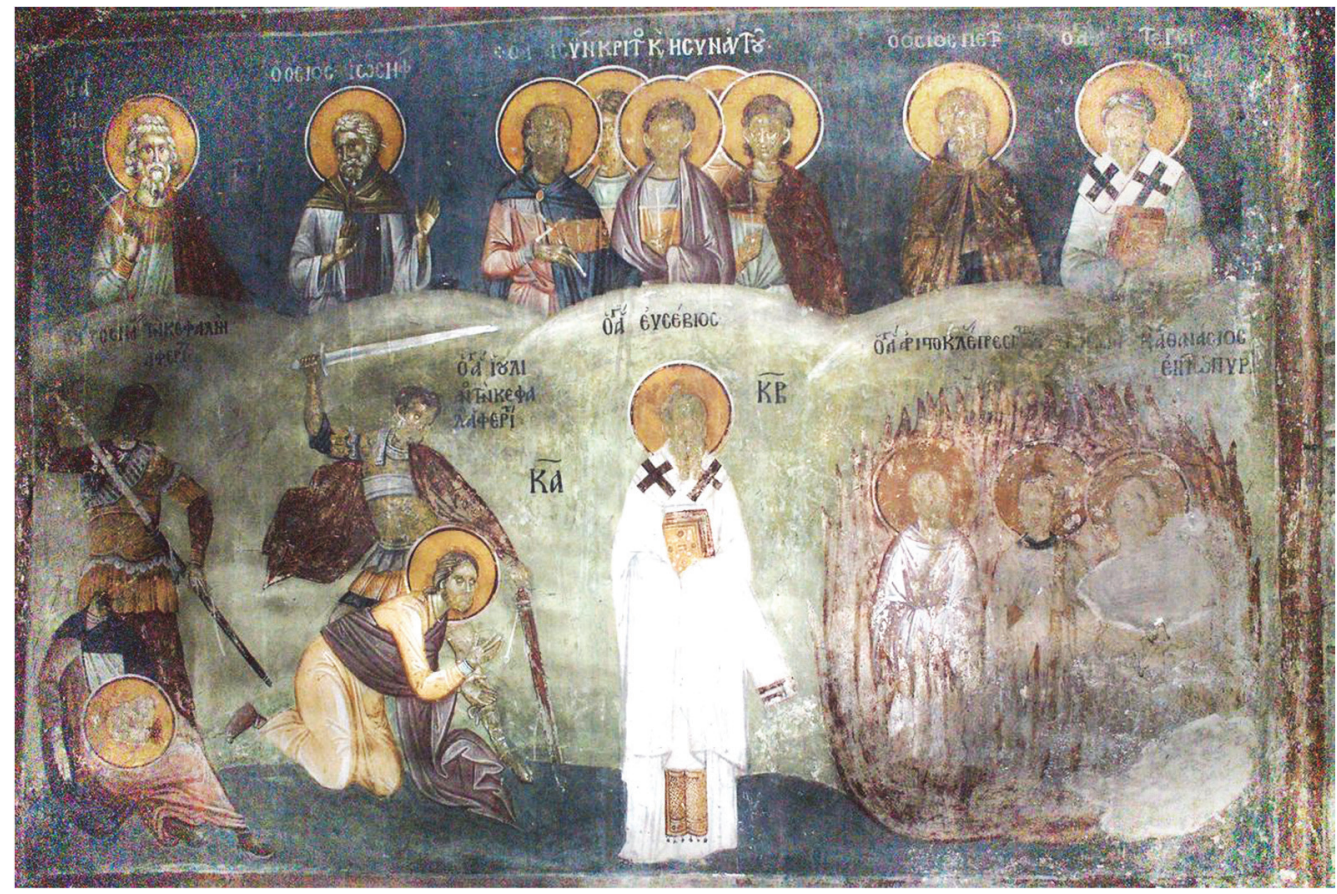

Fig. 2) Fresco of the Calendar of June at Gračanica

(Source: https://www.blagofund.org/Archives/Gracanica/exhibits/digital/little-nw/large/little-nw-41.jpg)

${ }^{57}$ On the research conducted at Apollonia-Sozopolis see Belke - Mersich 1990, 387-388; Özsait et al. 2013, 225-239.

${ }^{58}$ See Foss 2002, 135 n. 41. The architectural remains of churches found in the area are discussed by Belke - Mersich 1990, 311.

${ }^{59}$ For the monastery of Gračanica and its dating see Curčić 1988, 37-42 and 150-152. 
Remarkably, this inclusion of the saint in the iconographical programme of the church is not mentioned by most scholars who have dealt with the monastery of Gračanica. He is missing from the description of the frescoes by B. Todić, unlike saint Julianus depicted next to him. ${ }^{60}$ More importantly, he was not recognized by Walter, who has written an article on a scene from the monastery. ${ }^{61}$ His name is mentioned in another monograph on the frescoes by B. Živković ${ }^{62}$, but the latter appears to have taken both saints, Zosimos and Julianus, to be a linked pair. The calendar scenes seem to follow the Synaxarium, according to which Saint Julianus was celebrated on the $21^{\text {st }}$ of June. ${ }^{63}$ However, whereas the depiction of Julianus is accompanied by the figure $\overline{\kappa \alpha}\left(=21^{\text {st }}\right)$, the fresco indicates no date for Zosimos. It appears that the date for the veneration of Zosimos, which according to the Synaxarium would be the $20^{\text {th }}$ of June ${ }^{64}$, has been omitted.

As well as being incorporated in the Synaxarium and the Menaion for June, the depiction of Saint Zosimos in the calendar series of the Gračanica church suggests some form of veneration of the saint, as one of the martyrs and saints that were commemorated during this month. In any case, the fresco provides decisive proof that the saint had been incorporated in the iconography of Byzantine saints by the $14^{\text {th }}$ century, some 500 years prior to the preparation of his icon and the erection of his church in Bulgarian Sozopol.

\section{Saint Zosimos and Sozopol}

There are no elements in the Passio which suggest a link with Sozopolis in Thrace (modern Sozopol in Bulgaria). This association was a later construct, based on the identity of the city names. Like Pisidian Apollonia, Apollonia Pontica had been renamed Sozopolis, something that had taken place by AD 431, when the new name appears in the lists of the Ecumenical Council held at Ephesos. ${ }^{65}$ At some point, the Bulgarian city also came to house the cult of Saint Zosimos, but the evidence for this establishment is late.

The small church of Saint Zosimos in Sozopol is located close to the seashore, some $200 \mathrm{~m}$ south from the church of Saint Cyril and Methodius in the centre of the old town (Fig. 3). It belongs to the single-nave and single-apse type and occupies an area of $172 \mathrm{~m}^{2}$. Several steps provide access from the west entrance to the slightly sunken floor level. The interior has wooden chairs and the bishop's throne in the middle of the southern wall. The altar is separated from the naos by a wooden iconostasis, containing two rows of icons. ${ }^{66}$ A significant place in this composition is occupied by the icon of the patron saint which is succinctly described by Walter. ${ }^{67}$ The depiction of the saint in the centre, holding his severed head in his right hand, is surrounded by ten biographical scenes which correspond closely to the text of his Passio.

\footnotetext{
${ }^{60}$ Todić 1988, 106 and 417-419.

${ }^{61}$ Walter 1978, 183-200.

62 Živković 1989, Coupole Nord-Ouest.

${ }^{63}$ Synax. CP, col. 759-762. AASS, Ian. I, 579-587, however, places his feast day on January 9.

${ }^{64}$ Synax. CP, col. 757.

${ }^{65}$ See Kazhdan 1991, 1933.

${ }^{66}$ Description after Shterionov 2017, 36.

${ }^{67}$ Walter 2001, 42.
} 


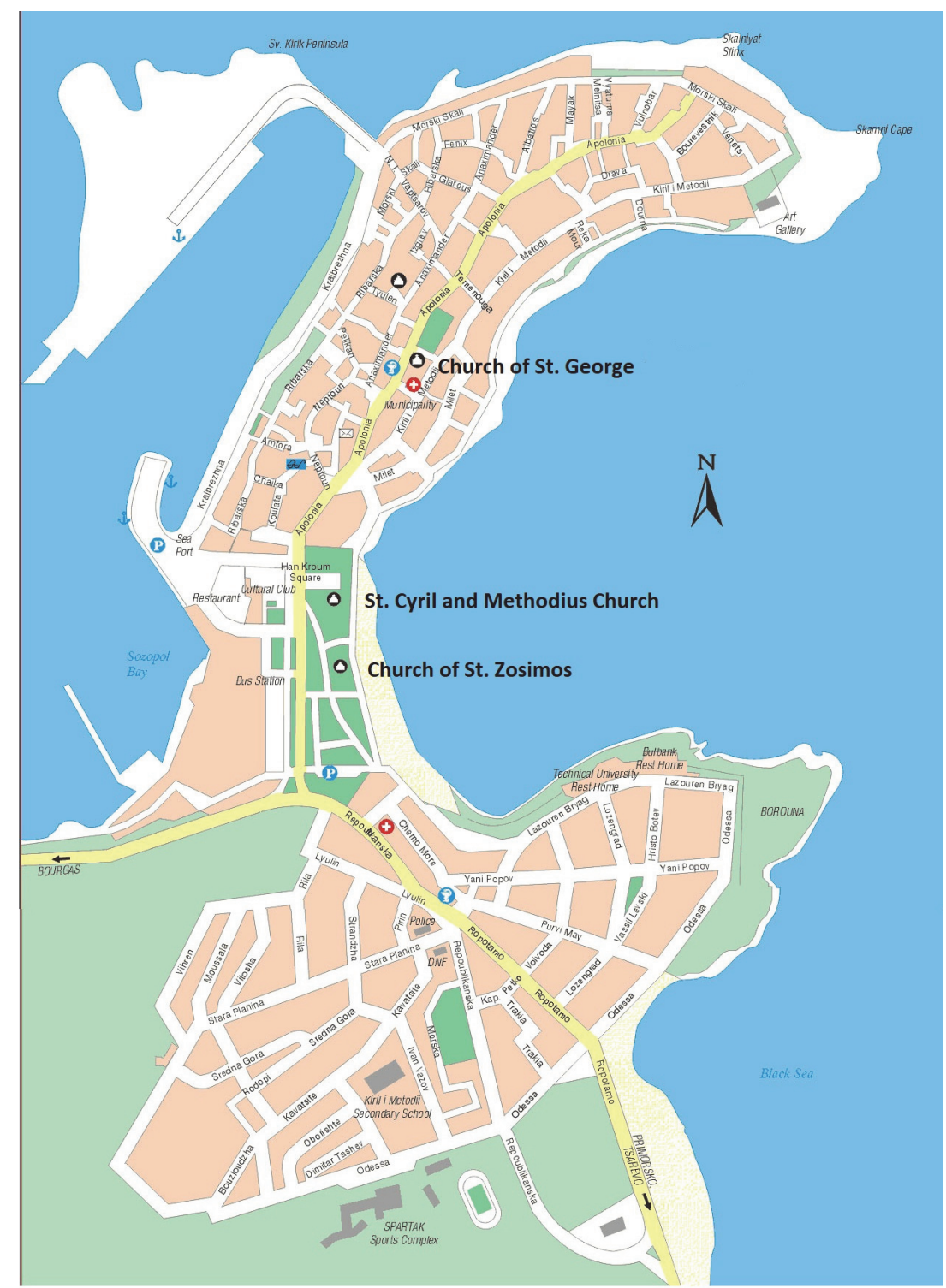

Fig. 3) Plan of the city of Sozopol (Source: http://sozopol8130.blogspot.com/2011/05/blog-post_25.html)

A marble plaque depicting Saint Zosimos as a warrior is built above the entrance of the church (Fig. 4 and 5). In addition to the name and origin of the saint, the inscription on the relief mentions the year 1857. Scholars understandably considered this to be the construction year of the sanctuary ${ }^{68}$ However, information from the city's archives, recently cited by S. Shterionov in his work about the orthodox tradition in Sozopol, ${ }^{69}$ reveals that the local authorities initially agreed on the construction in 1858. This is clear from the contract between the sponsors and the builders of the church, quoted by Shterionov:

Contract between Dim. N. Kourtoglou, Antonios Galias, N. Georgiou, Alexandros Georgiou and Michael Vasilikou, being one of the parties hereto, and Pavlos Hristou and Hristos Petrou, builders, the latter being the other party hereto, for the construction of the church of Saint Zosimos; this church to be rectangular in shape, its length to be 14

\footnotetext{
${ }^{68}$ This influenced Walter's description (Idem 2001, 41), although he does not mention the plaque.
}

${ }^{69}$ Shterionov 2017. 
ankles and its width to be 8, with 5 hatils, 2 planks, as usual, with mortar inside and outside with woven rods, 7 large windows and 2 small windows made of white stone, and the corners and the large gates, church chairs next to the iconostasis and next to the Despot's throne should be the pangar and the proskynetarion, 2 stands, the floor should be tiled, special tekeliden ceiling; the key should be handed over against (payment of) 3250 kuruş ... in Sozopol, 25 May $1858 .^{70}$

This not only provides information about the exact date of the agreement to build the church, its facilities and infrastructure, but also gives the names of the members the committee who oversaw the project. Almost all the names of the sponsors and builders are Greek, and the cult was closely linked to the city's Greek Orthodox community.

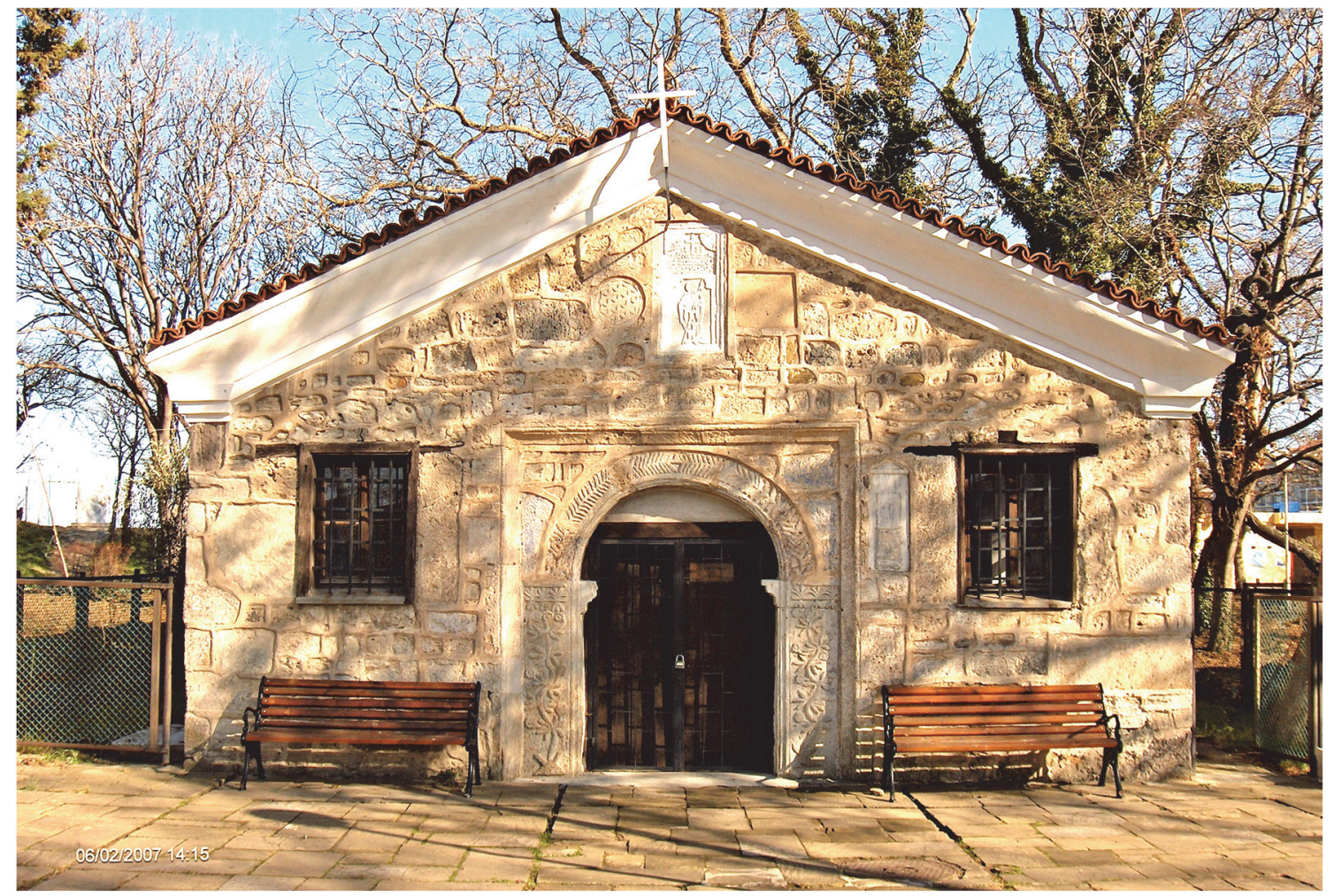

Fig. 4) View of the church of Saint Zosimos at Sozopol (Source: Archaeological Museum of Sozopol)

The presence of Greeks in Sozopol dates long before Christian times, from the $7^{\text {th }}$ century BC onwards, when the city was established as a colony of Miletos under the name of Apollonia. ${ }^{71}$ It was first attested as Sozopolis in the lists of clergy present at the Council of Ephesos (431), when a bishop called Athanasius headed the local Christian congregations of Sozopolis and neighbouring Debeltus (Deultum). ${ }^{72}$

Apollo was worshipped in many Black Sea cities ${ }^{73}$, and his cult at Apollonia was particularly notable. According to Strabo's Geography, the temple of Apollo housed a colossal statue of the god,

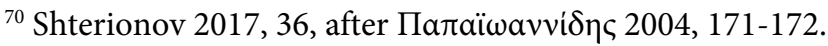

${ }^{71}$ See Lazarov 1998, 86.

72 “Athanasius episcopus Debelti \& Sozopolis”, Mansi, vol. V, col. 590 D; Le Quien, vol. 1, col. 1181-1182.

${ }^{73}$ On the worship of Apollo in the Black Sea area see Ustinova 2009, 281-287.
} 
the work of the famous Greek sculptor Kalamis, which was later carried off by Marcus Lucullus to Rome. ${ }^{74}$ The name change in late antiquity must have been motivated by the adoption of Christianity. The 'defeat' that Apollo suffered in this city in the course of its Christianisation is symbolised by a votive inscription to Apollo, re-used as a spolium in an early Christian basilica on the island of Saint Kirik ${ }^{75}$ where his temple is supposed to have existed. ${ }^{76}$

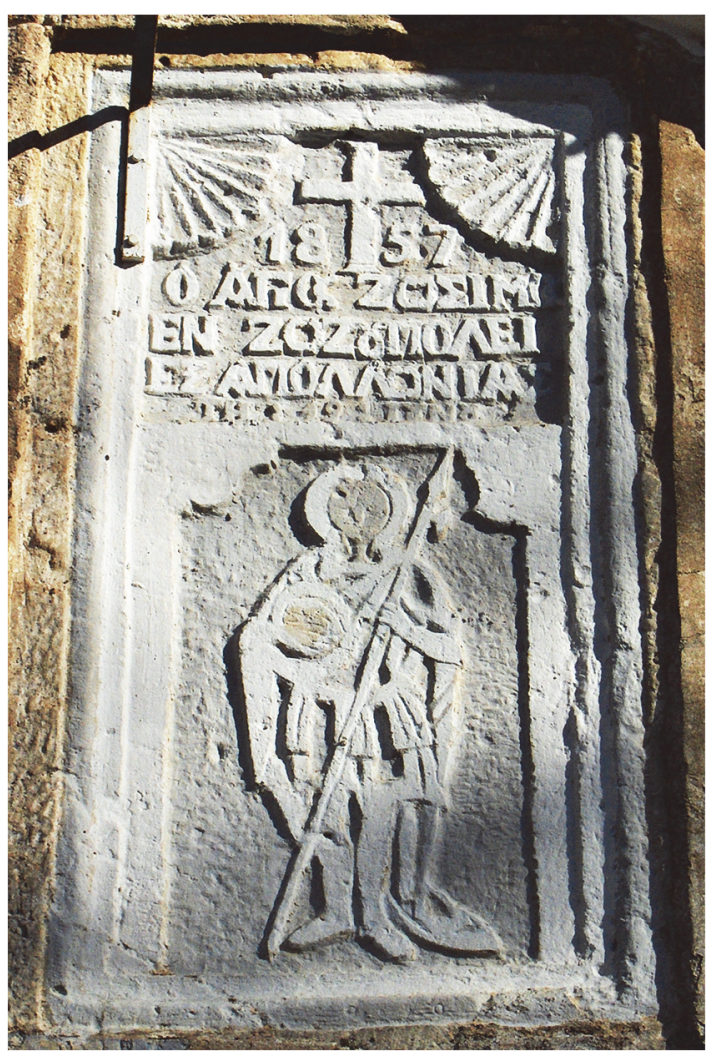

Fig. 5) Marble plaque above the entrance to the church of Saint Zosimos at Sozopol (Source: Archaeological Museum of Sozopol)

One important element regarding the evidence cited from the city's archive, is the fact that the contract offers no indication that an earlier church of Saint Zosimos existed in the same place. Since it mentions "construction", not "reconstruction", it does not support the view that there was an earlier church dedicated to the saint, as Walter suggests based on oral tradition ${ }^{77}$, and no archaeological evidence is available to support this theory. ${ }^{78}$ Nevertheless, the belief of the existence of a structure from medieval times is widespread in popular literature that mentions the church and its history. ${ }^{79}$ Is there any ground to consider such a possibility? Two elements speak in favour of this assumption. First, according to $S$. Shterionov's description of the current church, its construction involved the reuse of materials from older religious buildings, as is also the case with other churches in Sozopol..$^{80} \mathrm{~A}$ look at the façade is enough to recognize some of these spolia, although it is not clear what kind of buildings they originally belonged to. This building material is likely to have been collected in the immediate vicinity. In this respect, it is important to turn to the local archaeological context for more insight. This leads us to a second reason why the existence of an earlier Christian sanctuary in this part of the city should be taken into consideration.

${ }^{74}$ Strab. 7,6,1; this statue is also reported by Plin. Nat. Hist. 34.18 as standing on the Roman Capitoline hill.

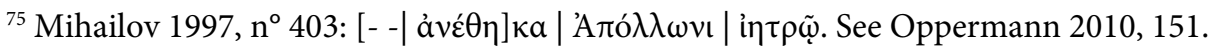

${ }^{76}$ On different hypotheses concerning its location see Konova 2006, 71-72.

77 Walter 2001, 41.

${ }^{78}$ For this information and other valuable remarks concerning the archaeological situation in the city, I wish to express my gratitude to D. Nedev of the Archaeological Museum of Sozopol (M. Prodanova).

79 This is very widespread among newspaper accounts and official websites presenting the cultural heritage of Sozopol and its churches, see e.g. http://visitburgas.org/bg/tsarkvi-v-sozopol (last visited on $12 / 03 / 2020)$.

${ }^{80}$ Shterionov 2017, 37. 
The area where Saint Zosimos' church was constructed - the modern Maritime Garden encompassed one of the main necropoleis of Sozopolis, the ancient Apollonia. The necropolis was used as early as the second half of the $3^{\text {rd }}$ century $\mathrm{BC}^{81}$ and remained in use until 1890 , when it was relocated. ${ }^{82}$ As Shterionov points out, the current church was initially built as a cemetery church, and it became one of the active places of worship in the centre of the old town only after the relocation of the necropolis. ${ }^{83}$

In view of the long history of the necropolis, it is possible that one or several Christian shrines existed in the place occupied by the modern church of Saint Zosimos, given the tradition of venerating martyrs by erecting cemetery chapels and churches in Christian times, and the wish of Christians to be buried close to (martyred) saints. ${ }^{84}$ There are many examples from the territory of Lower Moesia and Thrace, e. g. the martyria from the necropoleis at Philippopolis and Augusta Traiana ${ }^{85}$ The integration of Saint Zosimos in the early Christian community would not be a surprise. On the other hand, if such a church existed, the city annals carry no record of the fact.

Although Zosimos can be fitted into the tradition of warrior saints, ${ }^{86}$ the iconography used in his icon, prepared for the church by the painter Demetrius of Sozopol, emphasised his martyrdom by depicting him after his execution as kephalophoros. The importance of the cult of Saint George at Sozopol helps to elucidate why this iconography was chosen. Although oral tradition reckoned that Zosimos was the protector of Sozopol, ${ }^{87}$ possibly because the city's name featured in the Passio, the cult of Saint George was the more important of the two. Not only was the church of Saint George in the centre of the old town much larger than the church of Zosimos in the Maritime Garden, it was also much older. According to a Greek inscription, revealed during one of its reconstructions, the current building dates to 1697 , under bishop Kallinikos. ${ }^{88}$

The original dedication to "Saint George Megalomartyr", mentioned in the inscription, was changed to "Saint Clement" in $1914{ }^{89}$ in the context of the anti-Greek movement which took place in Bulgaria at that time, but the name of the original patron saint was restored in $1951 .{ }^{90}$ Whereas originally there had been no further specification of the great martyr, George appears in

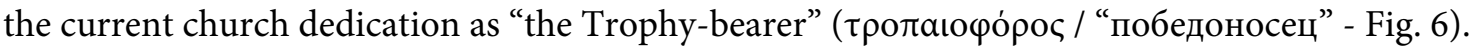

\footnotetext{
${ }^{81}$ See Baralis - Panayotova 2013, 241-242.

${ }^{82}$ See Shterionov 2017, 34.

${ }^{83}$ Ibidem.

${ }^{84}$ See Brown 1981, 1-22; Yasin 2009.

${ }^{85}$ See Topalilov - Ljubenova 2010, 67.

${ }^{86}$ See Walter 2003, 244.

${ }^{87}$ See Paskaleva 1977, 9.

${ }^{88}$ See Shterionov 2017, 29: "This holiest temple dedicated to the Saint Megalomartyr George was raised

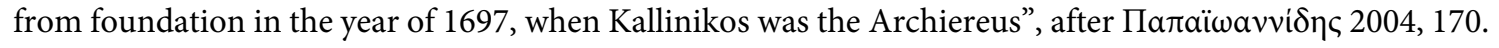

${ }^{89}$ See Shterionov 2017, 30.

${ }^{90}$ Ibidem.
} 


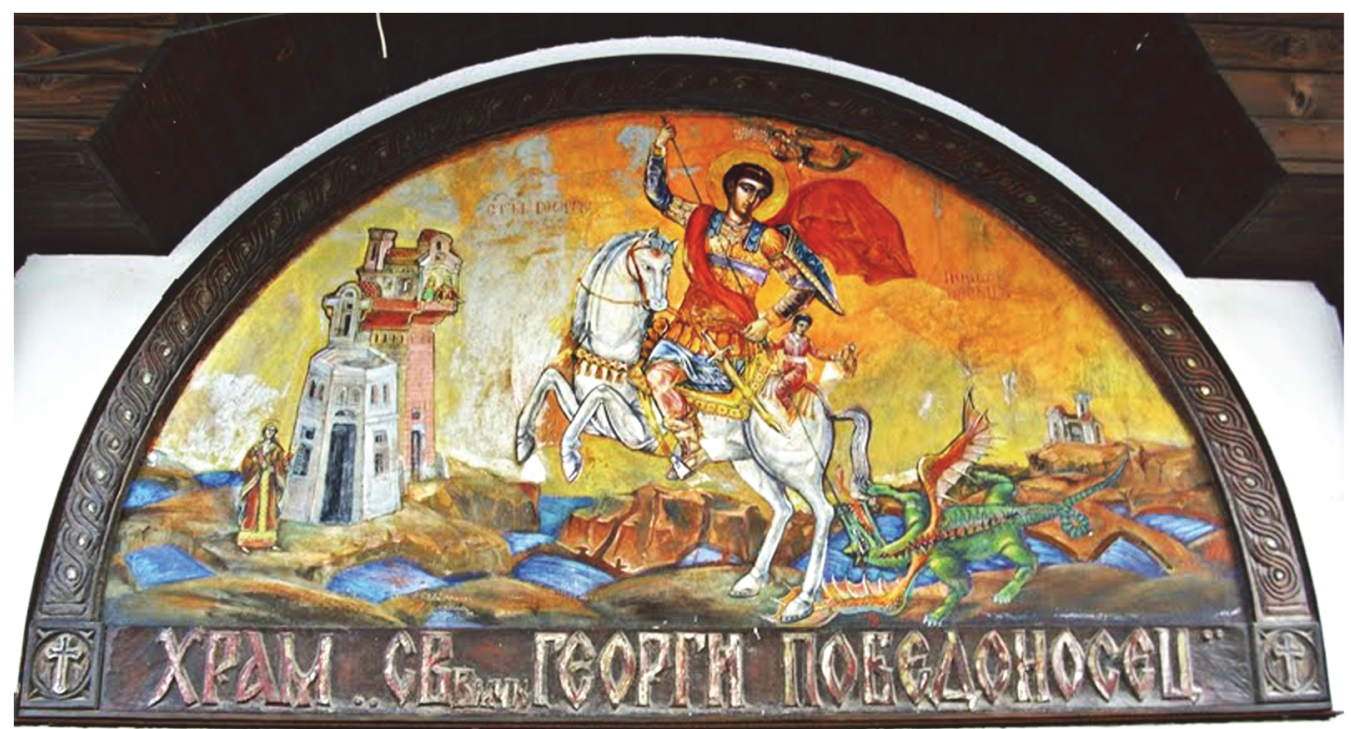

Fig. 6) Icon of Saint George at Sozopol (Source: http://sozopol8130.blogspot.com/2011/03/blog-post_26.html)

Whether or not such an addition to the martyr's name was intended from the beginning, but left out in the donor's inscription itself, is impossible to tell. As Walter points out in his study on warrior saints, George is best known as $\tau \rho \circ$ жаı$\varphi$ ó $\rho \circ$, a definition closely related to his status as an army officer. ${ }^{91}$ Most images of the saint, including the iconography in his church in Sozopol, accordingly depicts him as victorious in battle and acting as a protector against evil..$^{92}$ The notion of trophybearer seems to play an essential role in one specific iconographical type: the depiction as kephalophoros or "head-bearer", attested from the $16^{\text {th }}$ century onwards. ${ }^{93}$ The "trophy" carried by him in this case is his own severed head, in accordance with popular martyrs' iconography. ${ }^{94}$ In Sozopol, however, the saint who holds his head in his hands is Saint Zosimos and not Saint George (Fig. 7). In local iconography, Saint George has been stylised as a victorious warrior, while Saint Zosimos has the iconography of the martyr saint, which was appropriate to the funerary function of his church. It is possible that at Sozopol the profiles of the saints might have been carefully adjusted in relation to one another.

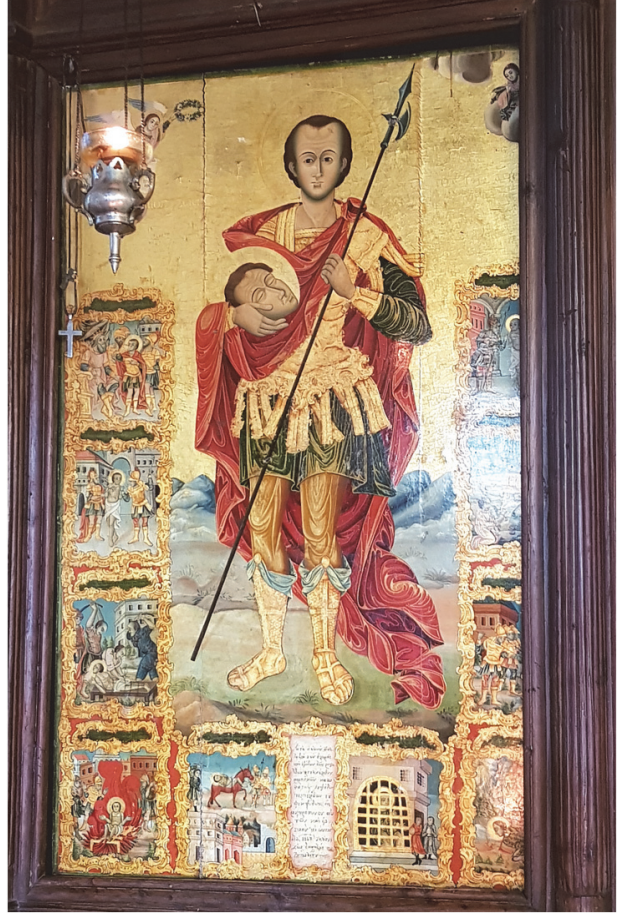

Fig. 7) Icon of Saint Zosimos at Sozopol (Picture taken by Maya Prodanova)

As mentioned above, the construction of Saint Zosimos' church in Bulgarian Sozopol was initiated by the local Greek Orthodox community. The icon of Zosimos by the painter Demetrius

\footnotetext{
${ }^{91}$ Walter 2003, 109 and 138.

${ }^{92}$ Idem, 125-134.

${ }^{93}$ Idem, 142-143.

${ }^{94}$ Idem, 143-144.
} 
of Sozopol is the oldest artefact available locally providing material evidence for the saint's veneration. The icon was painted in 1847, i.e. some 10 years earlier than the church building itself, perhaps in preparation for the construction. Furthermore, according to the account of Sozopol's library collection by K. Papaioannidis, two akolouthia or arrangements of a Divine Service for Saint Zosimos, written in 1875, were kept in the church of Saint George. ${ }^{95}$ Combined with the construction date of the church in 1858, the creation of these special liturgies enhance the impression that the cult was relatively new at that time. Their location in the church of Saint George supports the theory that this was the more important cult, as already suggested by the relationship of the two cult images. Nevertheless, the possibility that the Zosimos cult was 'rediscovered' in this period cannot be completely ruled out, corresponding to the locally persistent oral tradition that the saint had been venerated previously in the city. ${ }^{96}$

The localised nature of his worship, certainly attested only at Sozopol, is remarkable. Although Zosimos was included in the Menaion for June and depicted in the calendar frescoes, he obviously did not enjoy the popularity of other soldier saints - saint George, saint Demetrios, saint Theodore - who were all widely venerated and honoured with numerous churches throughout the Christian world. How then did this specific cult of a Pisidian martyr end up on the western shore of the Black Sea? The historical circumstances of the Late Byzantine period can perhaps help to explain the translatio. The conquest of the Pisidian city by Seljuk Turks in AD 1182, following the major Byzantine defeat at the battle of Myriokephalon in neighbouring Phrygia in September 1176 , led by 1190 to another name change, when it became the Seljuk settlement of Uluborlu. ${ }^{97}$ The loss of the town to Muslim control may have prompted the transfer of the cult (and any associated relics) to a new community sometime after the $12^{\text {th }}$ century. After this, the Byzantine Empire tried to compensate for the loss of territory to the Seljuks in Asia Minor by transferring some of its centres to the North. The Black Sea cities are known to have gradually replaced the Anatolian cities as commercial, administrative and cultural centres. ${ }^{98}$ One could envisage the moving/saving of the cults and relics of saints to be part of such a relocation..$^{99}$

Yet, this translation could have occurred at any point after the fall of Pisidian Sozopolis. Walter mentions how many Greeks of Constantinople settled in Sozopol after the Turkish conquest of the Byzantine capital in $1453^{100}$; it is possible that they brought the cult with them. Moreover, there was still a significant Greek-speaking population in $19^{\text {th }}$ century Pisidia ${ }^{101}$ and Christian Greeks from Uluborlu may have introduced Saint Zosimos at Sozopol as late as the first half of

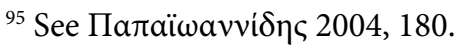

${ }^{96}$ Including the belief that Saint Zosimos' church has been constructed on that particular place in the city because an old icon depicting the saint was found there, see Paskaleva 1977, 9.

${ }^{97}$ See Nicetae Choniatae Historia, 262; Belke - Mersich 1990, 387.

${ }^{98}$ See Kamperides 1993, 26.

${ }^{99}$ From the early Middle Ages, the translatio or movement of relics from one location to another in times of war are documented, see Lester 2017, 92.

${ }^{100}$ Walter 2001, 41.

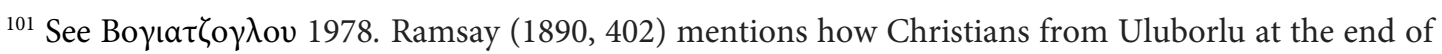
the $19^{\text {th }}$ century went on annual pilgrimage to the nearby spring of Hagiasma near Yassiören (ancient Tymandos).
} 
the $19^{\text {th }}$ century. In any case, what choice could have been better than Sozopolis on the Black Sea, as a former Apollonia, to become Zosimos' new home town?

\section{Conclusion}

This paper set out to trace the cult of Saint Zosimos back to its roots, in the city of ApolloniaSozopolis in the region of Pisidia, to amend an erroneous attribution of his origins to the Bulgarian city of Sozopol. Several elements present in the text of his Passio could be singled out which clearly corroborate the Asia Minor origin.

The Passio could be characterised as a product of Late Antiquity, written between the late $4^{\text {th }}$ and middle of the $6^{\text {th }}$ century AD by somebody with knowledge of the region of Pisidia. This was an age that witnessed a flurry of hagiography as communities were looking for new protectors now that the gods of old could no longer fulfil that function. Perhaps the creation of the martyr act should be seen in the context of the competition for ecclesiastical prominence between the cities of the region, as Apollonia-Sozopolis may have wanted to cash in on its status as one of the earliest centres of Christianity.

Nevertheless, no material traces of the cult have been identified in Pisidia so far. The saint was included in the Menaion for June and shown in a calendar fresco at Gračanica in Kosovo, but the Bulgarian city of Sozopol is the only location where the cult of Saint Zosimos is actually attested. A church dedicated to the saint and housing his icon was built in the area of an ancient necropolis in the mid- $19^{\text {th }}$ century. It is possible that the cult in Sozopol has an older origin, but there is no evidence for earlier veneration or the translation of the cult from Pisidia, leaving many questions concerning Saint Zosimos unanswered.

\section{Bibliography}

\section{Ancient Works}

AASS

Acta Sanctorum, Antverpiae - Bruxellis - Tongerloae - Parisiis 16431940.

Basil, Letters

R. J. Deferrari - M. R. P. McGuire (eds.), Basil, Letters, vol. IV: Letters 249-368, Cambridge (MA) 1934 (Loeb Classical Library 270).

$B H G$

Bibliotheca Hagiographica Graeca, 5 vols., ed. F. Halkin (Brussels, 1957-84).

Codex Lesbiacus Leimonos A. Spanos, Codex Lesbiacus Leimonos 11: Annotated Critical Edition 11 of an Unpublished Byzantine Menaion for June, Berlin 2010.

Le Quien

M. Le Quien, Oriens christianus, in quatuor patriarchatus digestus: quo exhibentur ecclesiae, patriarchae, caeterique praesules totius orientis, vol. 1, Paris 1740.

Mansi

J. D. Mansi (ed.), Sacrorum Conciliorum Nova et Amplissima Collectio, vol. III, Florence 1759.

Menaion

B. Koutloumousianos (ed.), Menaion, Venice 1846.

$M L$ II

B. Latyšev, Menologii anonymi byzantini saeculi X quae supersunt. Fasciculus alter, menses Iunium, Iulium, Augustum continens, St. Petersburg 1912 (Sumptibus Caesareae Academiae scientiarum e codice Hierosolymitano S. Sepulcri 17). 
Menologium Graecorum J.-P. Migne (ed.), Menologium Graecorum Basilii Porphyrogeniti imperatoris jussu editum, Paris 1863 (Patrologia Graeca 117).

Nicetae Choniatae Historia I. A. van Dieten (ed.), Nicetae Choniatae Historia, Berlin 1975 (Corpus fontium historiae Byzantinae 11).

Notitiae episcopatuum J. Darrouzès, Notitiae episcopatuum ecclesiae Constantinopolitae. Texte critique, introduction et notes, Paris 1981.

Plin. Nat. Hist.

J. Bostock - H.T. Riley (eds.), The Natural History of Pliny, London 1855.

Plin. Epist. $\quad$ B. Radice (ed.), Letters Volume II: Books 8-10. Panegyricus, Cambridge (MA) 1969.

Roman Martyrology $\quad$ R. J. Collins (ed.), The Roman Martyrology Published by order of Gregory XIII, Westminster 1946.

Strab.

H. L. Jones (ed.), The Geography of Strabo, Cambridge (MA) London 1924.

Synax. CP H. Delehaye (ed.) Synaxarium Ecclesiae Constantinopolitanae: Synaxarium mensis junii, Brussels 1902, 721-790.

Vie de Théodore de Sykeon A. Festugière (ed.), Vie de Théodore de Sykeon, Brussels 1970.

\section{Secondary sources}

Baldwin - Kazhdan 1991 B. Baldwin - A. Kazhdan, Apolllonaris, in: A. Kazhdan (ed.) The Oxford Dictionary of Byzantium, Oxford 1991, 136.

Baralis - Panayotova 2013 A. Baralis - K. Panayotova, Burial Enclosures and Spatial Organization of the Classical and Early Hellenistic Necropoleis of Apollonia Pontica, Kalfata/Budjaka Area, in: K. Sporn (ed.), Griechische Grabbezirke klassischer Zeit: Normen und Regionalismen. Akten des Internationalen Kolloquiums am Deutschen Archäologischen Institut, Abteilung Athen, 20.-21. November 2009, München, 2013, 241260 (Athenaia 6).

Beihammer 2017 A. D. Beihammer, Byzantium and the Emergence of Muslim-Turkish Anatolia, ca. 1040-1130, London 2017.

Belke - Mersich $1990 \quad$ K. Belke - N. Mersich, Phrygien und Pisidien, Vienna 1990 (Tabula Imperii Byzantini 7).

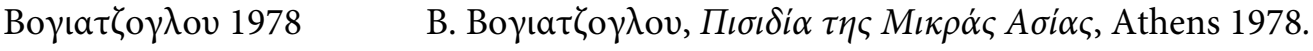

Brown 1981

P. Brown, The Cult of the Saints. Its Rise and Function in Latin Christianity, Chicago 1981.

Brubaker - Haldon 2011 L. Brubaker - J. Haldon, Byzantium in the Iconoclast Era c. 680-850: A History, Cambridge 2011.

Buckler - Calder - Guthrie W.H. Buckler - W.M. Calder - W.K.C. Guthrie, Monumenta Asiae 1933 Minoris Antiqua, IV: Eastern Asia and Western Galatia, Manchester 1933. 
Carlà 2010

F. Carlà, Milan, Ravenna, Rome: Some reflections on the cults of the saints and on civic politics in late antique Italy, Rivista di Storia e Letteratura Religiosa 46 no. 2, 2010, 197-272.

Christol - Drew-Bear 1987 M. Christol - T. Drew-Bear, Un castellum romain près d'Apamée de Phrygie, Vienna 1987, 13-19 (Ergänzungsbände zu den Tituli Asiae Minoris 12).

Christol - Drew-Bear 1999 M. Christol - T. Drew-Bear, Antioche de Pisidie: Capital provincial et l'oeuvre de M. Valerius Diogenes, Antiquité tardive 7, 1999, 39-71.

Cohen 1995 G. Cohen, The Hellenistic Settlements in Europe, the Islands, and Asia Minor, Berkeley 1995.

Ćurčić 1988

Destephen 2015

S. Ćurčić, Gračanica. Istorija i architektura, Belgrade - Pristina 1988.

S. Destephen, Martyrs locaux et cultes civiques en Asie Mineure, in : J.P. Caillet - S. Destephen - B. Dumézil - H. Inglebert (eds.), Des dieux civiques aux saints patrons (IVe - VIIe siècle), Paris 2015, 59-116 (Textes, images et monuments de l'Antiquité au Haut Moyen Âge 12).

Efthymiadis et al. 2011

S. Efthymiadis et al., Greek Hagiography in Late Antiquity (Fourth Seventh Centuries), in: S. Efthymiadis (ed.), Ashgate Research Companion to Greek Hagiography, I: Periods and Places, Farnham 2011, 35-94.

Foss 2002

C. Foss, Pilgrimage in Medieval Asia Minor, Dumbarton Oaks Papers 56, 2002, 129-151.

Foss - Winfield 1986 C. Foss - D. Winfield, Byzantine Fortifications: An Introduction, Praetoria 1986.

Gregory 1991

T. E. Gregory, Severos, in: A. Kazhdan (ed.), The Oxford Dictionary of Byzantium, Oxford 1991, 1884-1885.

Hürmüzlü - De Giorgi Iversen 2009

B. Hürmüzlü - A. De Giorgi - P. A. Iversen, New Research in Northwestern Pisidia: Ancient Konane (Conana) and its Territory, Colloquium Anatolicum 8, 2009, 197-220.

Iversen 2015

P. Iversen, Inscriptions from Northwest Pisidia, EpigrAnat 48, 2015, 1-85.

Jones et al. 1971

A. H. M. Jones et al. (eds.), Prosopography of the Later Roman Empire, vol. I: AD 260-395, Cambridge 1971.

Kamperides 1993

L. Kamperides, The Greek Monasteries of Sozopolis: XIV-XVII Centuries, Thessaloniki 1993.

Kazhdan 1991

A. Kazhdan, Sozopolis in Thrace, in: A. Kazhdan (ed.), The Oxford Dictionary of Byzantium, Oxford 1991, 1933.

Konova 2006

L. Konova, Once more about the Temenos of Apollo Ietros in Apollonia Pontica. Attempt at Reconsideration, ISTROS 1, 2006, 71-84.

Lazarov 1998

M. Lazarov, Notizen zur griechischen Kolonisation am westlichen Schwarzen Meer: Schriftquellen und archäologische Denkmäler, in: G. R. Tsetskhladze (ed.), The Greek Colonisation of the Black Sea 
Lester 2017

McKenchie 2019

Mehl 1986

Métivier 2012

Mihailov 1997

Mitchell 1976

Mitchell 1993

Mitchell - Waelkens 1998

Nollé 1993

Oppermann 2010

Özsait et al. 2013

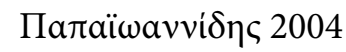

Paskaleva 1977

Paskaleva 2019
Area. Historical Interpretation of Archaeology, Stuttgart 1998, 85-95 (Historia Einzelschriften 121).

A. E. Lester, Translation and appropriation: Greek relics in the Latin West in the aftermath of the Fourth Crusade, Studies in Church History 3, 2017, 88-117.

P. McKenchie, Christianizing Asia Minor: Conversion, Communities and Social Change in the Pre-Constantinian Era, Cambridge 2019.

A. Mehl, Seleukos Nikator und sein Reich, Leuven 1986 (Studia Hellenistica).

S. Métivier, Byzantium in question in 13th century Seljuk Anatolia, in: G. Saint-Guillain - D. Stathakopoulos (eds.) Liquid \& Multiple: Individuals \& Identities in the $13^{\text {th }}$-Century Aegean, Paris 2012, 235-257.

G. Mihailov, Inscriptiones Graecae in Bulgaria repertae, vol. 1: Inscriptiones orae Ponti Euxini, Sofia 1997 (2nd edition).

S. Mitchell, Requisitioned transport in the Roman Empire: A new inscription from Pisidia, JRS 66, 1976, 106-131.

S. Mitchell, Anatolia: Land, Men and Gods in Asia Minor, II. The Rise of the Church, Oxford 1993.

S. Mitchell - M. Waelkens, Pisidian Antioch: The Site and its Monuments, London 1998.

J. Nollé, Die feindlichen Schwestern - Betrachtungen zur Rivalität der pamphylischen Städte, in: G. Dobesch - G. Rehrenböck (eds.), Die epigraphische und altertumskundliche Erforschung Kleinasiens. Hundert Jahre Kleinasiatische Kommission der Österreichischen Akademie der Wissenschaften. Akten des Symposiums von 23. Bis 25. Oktober 1990, Vienna 1993, 297-317 (Österreichische Akademie der Wissenschaften. Philosophisch-historische Klasse. Denkschriften 236).

M. Oppermann, Das frühe Christentum an der Westküste des Schwarzen Meeres und im anschliessenden Binnenland. Historische und archäologische Zeugnisse, Langenweißbach 2010 (Schriften des Zentrums für Archäologie und Kulturgeschichte des Schwarzmeerraumes 19).

M. Özsait et al., Nouvelles inscriptions sur le territoire d'Apollonia Mordiaion, Adalya 16, 2013, 225-239.

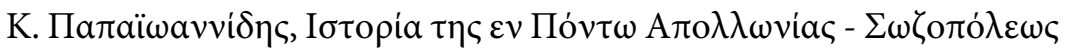

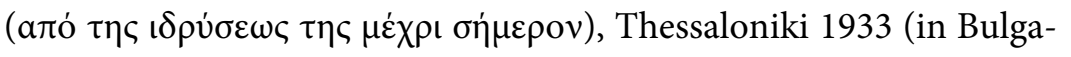
rian translation, Sofia 2004).

K. Paskaleva, Ikoni Ot Strandžanskija Kraj, Sofia 1977.

K. Paskaleva, St. Zosimos of Apollonia - Remarks on the Early Saintly Cults in Strandzha, in: A. Nikolov (ed.), The Cultural Heritage of Strandzha. Wealth, Risks, Challenges, Sofia 2019, 224-234. 
Ramsay 1890

Robert 1977

Robert 1980

Roueché 2007

Sauget 1966

Shterionov 2017

Smith 2012

Talloen 2015

Talloen forthcoming

Topalilov - Ljubenova

2010

Todić 1988

Ustinova 2009

Uytterhoeven - Poblome forthcoming

Vitale 2012

Vryonis 1964

Walter 1978

Walter 2001
W.M. Ramsay, The Historical Geography of Asia Minor, London 1890.

L. Robert, La titulature de Nicée et de Nicomedia: la gloire et la haine, HSCP 81, 1977, 1-39.

L. Robert, A travers l'Asie mineure : poètes et prosateurs, monnaies grecques, voyageurs et géographie, Paris 1980.

C. Roueché, From Aphrodisias to Stauropolis, Bulletin of the Institute of Classical Studies 50 no. 91, 2007, 183-192.

J. M. Sauget, Marina (Margherita), in: Bibliotheca Sanctorum, Vol. 8, Rome 1966, col. 1150-1160.

S. Shterionov, Orthodoxy in Sozopol. Past and Present, Sofia 2017.

R. R. R. Smith, Defacing the gods at Aphrodisias, in: B. Dignas - R. R.

R. Smith (eds.), Historical and Religious Memory in the Ancient World, Oxford 2012, 283-326.

P. Talloen, Cult in Pisidia: Religious Practice in Southwest Asia Minor from Alexander the Great to the Rise of Christianity, Turnhout 2015 (Studies in Eastern Mediterranean Archaeology 10).

P. Talloen, The road to salvation: Travel and the sacred along the Imperial Road in Pisidia, in: L. Vandeput et al. (eds.), Pathways of Communication. Roads and Routes in Anatolia from Prehistory to Seljuk Times, forthcoming.

I. Topalilov - A. Ljubenova, Neue Überlegungen zum hexakonchalen Martyrium von Philippopolis (Plovdiv, Bulgarien), Mitteilungen zur christlichen Archäologie 16, 2010, 59-70.

B. Todić, Gračanica. Slikarstvo, Belgrade - Pristina 1988.

Y. Ustinova, Apollo Iatros: A Greek God of Pontic Origin, in: K. Stähler (ed.), Die Griechen und ihre Nachbarn am Nordrand des Schwarzen Meeres. Beiträge des Internationalen archäologischen Kolloquiums Münster 2001, Münster 2009, 281-287 (Eikon 9).

I. Uytterhoeven - J. Poblome, In honour of the 'city's' patron and benefactor' C. Trebonius Proculus Mettius Modestus, governor of Lycia et Pamphylia, forthcoming.

M. Vitale, Eparchie und Koinon in Kleinasien von der ausgehenden Republik bis ins 3. Jh. n.Chr., Bonn 2012 (Asia Minor Studien 67).

S. Vryonis, Problems in the history of Byzantine Anatolia, Tarih Araştırmaları Dergisi 1, 1964, 113-132.

C. Walter, Iconographical Sources for the Coronation of Milutin and Simonida at Gračanica, in: Vizantijska umetnost početkom XIV veka: naučni skup u Gračanici, Belgrade 1978, 183-200.

C. Walter, An Icon of Saint Zosimos of Sozopol, Analecta Bollandiana $119.1,2001,40-44$. 
Walter 2003

Yasin 2009

Zacos - Veglery 1972

Živković 1989
C. Walter, The Warrior Saints in Byzantine Art and Tradition, Aldershot 2003.

A. M. Yasin, Saints and Church Spaces in the Late Antique Mediterranean: Architecture, Cult and Community, Cambridge 2009.

G. Zacos - A. Veglery, Byzantine Lead Seals, I, Basel 1972.

B. Živković, Gračanica. Crteži fresaka, Belgrade 1989.

\section{Apollonia-Sozopolisli Zosimos}

Özet

Hıristiyan olmak için Roma ordusundan ayrıldıktan sonra imparator Traianus Dönemi'nde (M.S. 97-118) antik Pisidia ve Phrygia sınır bölgesinde (Türkiye'nin güneybatısında) şehit olduğu iddia edilen asker Aziz Apollonia-Sozopolisli Zosimos Rum Ortodoks Kilisesi tarafından Haziran ayinın 19'unda bayramı kutlanan ve nispeten ismi pek bilinmeyen bir azizdir. Modern araştırmalarda Batı Karadeniz kıyısındaki Roma eyaleti Thracia'da Apollonia Pontica - Sozopolis kökenli bir asker olduğu ve şehit olduğu Pisidia'daki Roma ordusundan istifa ettiği tartışılmaktadır. Thrakialı bir asker olarak Zosimos'un bu tanımlaması karışık kimlikler ya da daha ziyade karışık kökenlerden oluşan bir durumdur. Bu makalenin amacı ise azizle ilgili kaynaklarda adı geçen Apollonia-Sozopolis'in azize bugün hala ibadet edilen Bulgaristan'ın Sozopol (Süzebolu) kenti değil, aksine modern Türkiye'deki antik Pisidia'nın kuzeyinde bulunan aynı isme sahip bir kent olduğunu kanıtlamaktadır. 'Zosimos'un Çilesi isimli antik metinin analizi bunun için birkaç bulgu sunacaktır. Makale ayrıca 'Zosimos'un Çilesi'nin kökenini de araştırmaktadır: Metinde bahsi geçen birtakım unsurlar azizin şehitlik anlatısının büyük olasılıkla Geç Antik Dönem'de yazılmış azizlerle ilgili metin bolluğunun bir parçası olan geç antik bir kurgu olduğunu göstermektedir. Bu kurgu, Apollonia-Sozopolis'in 5. ve 6. yüzyıllar boyunca Pisidia eyaleti içindeki Erken Hıristiyanlığın önemli bir merkezi olarak konumunu vurgulamak için oluşturulmuş olabilir. Kosova'daki Graçaniça'da ve Bulgaristan'daki Süzebolu'da Zosimos'a saygı duyulduğuna dair devam eden dönemlerde de kanıtlar vardır ve makale, bu Pisidialı azizin kültünün bugün bile hala ona saygı beslenen Bulgaristan'daki Süzebolu'da neden merkezîleştiğini saptamaya çalışacaktır.

Anahtar Sözcükler: Aziz Zosimos, Apollonia-Sozopolis, Pisidia, Hagiyografi, Geç Antik Çağ.

\section{Zosimos of Apollonia-Sozopolis}

Abstract

Saint Zosimos of Apollonia-Sozopolis, a soldier who was reputedly martyred in the border region of ancient Pisidia and Phrygia (SW Turkey) during the reign of the emperor Trajan (98-117 AD) after resigning from the Roman army to become a Christian, is a relatively unknown saint celebrated by the Greek Orthodox Church on the $19^{\text {th }}$ of June. In modern scholarship, he is discussed as a soldier who originated from ancient Apollonia Pontica - Sozopolis in the Roman province of Thracia on the western Black Sea coast, and resigned from the Roman army in Pisidia, where he was martyred. This characterisation of Zosimos as a Thracian soldier is a case of mixed identities, or better, of mixed origins. It is the aim of this article to demonstrate that the ApolloniaSozopolis referred to in the sources concerning the saint is not the Bulgarian city of Sozopol where the saint is still worshipped today but the homonymous city located in the northwestern part of ancient Pisidia in modern Turkey. A textual analysis of the Passio of Zosimos will offer several 
indications for this. The article also looks for the origins of the Passio of Zosimos: several elements mentioned in the text demonstrate that the account of the saint's martyrdom was most probably a late antique construct, part of the abundance of hagiographical texts produced in late antiquity. It may have been composed to emphasize the position of Apollonia-Sozopolis as a major centre of early Christianity within the province of Pisidia during the $5^{\text {th }}$ and early $6^{\text {th }}$ centuries. There is subsequent evidence for the veneration of Zosimos at Gračanica in Kosovo and at Sozopol in Bulgaria, and the paper will try to establish why the cult of this Pisidian saint eventually came to be centred at Sozopol in Bulgaria, where he is still the object of veneration today.

Keywords: Saint Zosimos, Apollonia-Sozopolis, Pisidia, Hagiography, Late Antiquity. 